Linguista, Vol.2, No.2, Desember 2018, hal 106 - 112

ISSN (print): 2579-8944; ISSN (online): 2579-9037

Avaliable online at: http:/le-journal.unipma.ac.id/index.php/linguista

\title{
Pengaruh Penggunaan Model Pembelajaran Cooperative Reading and Composition (CIRC) dan Kemampuan Berpikir Kritis Terhadap Kemampuan Apresiasi Cerpen Siswa SDN Mrayan Kabupaten Ponorogo
}

\author{
Pamularsih \\ SDN 3 Mrayan, Kecamatan Ngaryun Ponorogo, Indonesia \\ e-mail: pamularsihspdsd@gmail.com
}

\begin{abstract}
Abstrak
Kemampuan apresiasi karya sastra sangat dipengaruhi oleh beberapa kemampuan yang lain. Kemampuan tersebut salah satunya adalah kemampuan berpikir kritis. Di dalam kemampuan berpikir kritis, kemampuan akademis siswa akan terbentuk. Dalam kaitannya dengan pembelajaran apresiasi cerpen, siswa dituntut untuk mampu menganalisa setiap unsur yang terdapat dalam cerpen. Tujuan utama penelitian ini adalah menganalisis Pengaruh Penggunaan Model Pembelajaran Cooperative Reading and Composition (CIRC) dan Kemampuan Berpikir Kritis Terhadap Kemampuan Apresiasi Cerpen. Penelitian ini berjenis kuantitatif eksperimen semu. Sampel dalam penelitian ini berjumlah 100 siswa. Pemilihan sampel dilakukan secara acak dengan mempertimbangkan karakteristik tertentu. Hasil temuan dalam penelitian ini adalah terdapat pengaruh penggunaan metode CIRC dan kemampuan berpikir kritis terhadap kemampuan apresiasi cerpen siswa.
\end{abstract}

Kata kunci: CIRC; berpikir kritis; cerpen; apresiasi

\section{The Effect of Using Cooperative Reading and Composition (CIRC) and Critical Thinking on Students' Short Story Appreciation Ability of SDN Mrayan Ponorogo Regency}

\begin{abstract}
The ability of appreciation of literary works is strongly influenced by several other abilities. One of the abilities is critical thinking. In the critical thinking, students' academic ability will be formed. In relation to learning the appreciation of short stories, students are required to be able to analyze every element contained in the short story. The main purpose of this study is to analyze the effect of using Cooperative Reading and Composition (CIRC) and critical thinking on students' short story appreciation ability. This study used quantitative quasi-experiment. The sample in this study was 100 students. The sample was randomly selected based on certain characteristics. The result shows that there is a significant effect of using CIRC method and critical thinking on students' short story appreciation ability.

Keywords: CIRC; critical thinking; short story; appreciation

\section{Pendahuluan}

Sejak diberlakukan Kurikulum 1975 sampai Kurikulum 2006 atau Kurikulum Tingkat Satuan Pendidikan (KTSP), mata pelajaran bahasa Indonesia adalah salah satu mata pelajaran yang memiliki peranan penting dalam dunia pendidikan. Dalam pengajaran bahasa Indonesia terdapat dua materi pokok yang diajarkan, yakni materi kebahasaan dan materi kesastraan. Keduanya telah direncanakan mendapat porsi yang seimbang, sehingga tidak ada yang dianakemaskan maupun dianaktirikan.
\end{abstract}


Namun, kenyataan di sekolah pengajaran mata pelajaran bahasa Indonesia kurang sesuai dengan apa yang direncanakan. Para guru lebih memprioritaskan materi kebahasaan daripada materi kesastraan. Hal itu disebabkan adanya anggapan bahwa materi kebahasaan lebih penting daripada materi kesastraan. Hal ini sesuai dengan pendapat Yudiono (2000: 47) yang menyatakan bahwa meskipun tidak dinyatakan secara terang-terangan, banyak orang yang masih menyepelekan pelajaran sastra. Pendapat para guru seperti di atas tidaklah tepat karena sastra sebenarnya bisa menjadi media untuk mengasah dan mengembangkan keterampilan berbahasa siswa.

Selaras dengan pendapat di atas, Kinayati (2006: 743) mengemukakan bahwa menurutnya sastra perlu diperkenalkan kepada siswa supaya mereka sadar akan adanya sastra sebagai bagian dari keterampilan berbahasa. Selain itu apresiasi sastra juga mampu memperkaya pengalaman, pandangan hidup, dan kepribadian siswa. Rahmanto (1988: 15) menyatakan bahwa sastra itu mempunyai relevansi dengan masalah-masalah dunia nyata, maka pengajaran sastra harus dipandang sebagai sesuatu yang penting yang patut menduduki tempat yang selayaknya.

Salah satu karya sastra yang dimasukkan dalam pembelajaran sastra adalah cerita pendek. Kegiatan pembelajaran ini sudah diberikan kepada siswa mulai mereka berada di sekolah dasar. Dengan pembelajaran cerita pendek sejak dini, nilai-nilai luhur yang terkandung dalam cerita pendek dapat tertanam kuat dalam diri anak. Hal ini sesuai dengan pendapat Toha dan Sarumpaet (2002: 16) yang menyatakan bahwa minat dan apresiasi pembaca hendaknya mulai dibangkitkan dan ditumbuhkan sejak dini, yaitu ketika pembaca masih berusia sekolah. Mutu dan tingkat pemahaman apresiasi sastra yang telah dilalui oleh siswa di sekolah akan menjadi modal bagi perkembangan lebih lanjut pada saat mereka nanti terjun sebagai anggota masyarakat.

Cerpen adalah salah satu genre karya sastra yang menarik untuk dibaca dan dipelajari. Cerpen juga merupakan salah satu jenis fiksi yang memiliki elemen cerita, plot, latar, tokoh yang lebih sempit daripada novel yang selesai di baca dalam sekali duduk. Oleh karena itu, cerita yang yang disajikan dalam cerpen terbatas hanya memiliki satu kisah atau satu peristiwa (Sumardjo, 2007: 202).

Dapat dipahamibahwa pembelajaran cerpen menjadi salah satu pembelajaran yang diperhitungkan. Di dalam cerpen terdapat nasehat-nasehat bagi generasi muda. Oleh karena itu cerpen menjadi salah satu karya sastra yang indah, menggambarkan suatu kejadian kesewaktuan yang menjadi inti dalam sebuah kisah cerita.

Hal tersebut semakin diperkuat oleh pendapat Musfiroh (2008: 19) yang menyatakan bahwa cerita pendek dapat digunakan oleh orang tua dan guru sebagai sarana mendidik dan membentuk kepribadian anak melalui pendekatan transmisi budaya atau cultural transmissionapproach. Dalam cerita, nilai-nilai luhur ditanamkan pada diri anak melalui penghayatan terhadap makna dan maksud cerita (meaning and intention of story). Oleh karena itu, Pusat Kurikulum Departemen Pendidikan Nasional mencantumkan materi cerita pendek sebagai salah satu materi bahasa Indonesia yang diajarkan di SD kelas VI. Dengan pembelajaran cerita pendek sejak SD, diharapkan peserta didik mampu mengambil nilai-nilai positif materi tersebut.

Nilai-nilai yang terkandung dalam cerita pendek dapat diperoleh dengan mengapresiasikannya. Apresiasi ini dapat dilakukan dengan cara membaca, mengidentifikasi unsur-unsur intrinsiknya, hingga menceritakan kembali isi cerita. 
Secara singkat, pembelajaran apresiasi cerita pendek dapat mengantarkan mereka memperoleh kemampuan berbahasa secara terpadu.

Namun, kenyataan di lapangan tidak sesuai dengan apa yang diharapkan. Pembelajaran apresiasi sastra sampai saat ini masih menjadi masalah secara umum karena kemampuan apresiasi sastra di tingkat SD masih rendah. Hal ini dapat dilihat dari proses maupun hasil pembelajaran. Ketidaksesuaian ini dapatdiindikatori oleh: siswa belum mampu menentukan unsur intrinsik cerita pendek, siswa belum mampu mengungkapkan makna dan nilai-nilai, serta siswa belum mampu menceritakan kembali isi cerita pendek.

Dalam ranah pembelajaran bahasa Indonesia, pembelajaran apresiasi cerita pendek masih tergolong rendah. Rendahnya kemampuan apresiasi cerita pendek siswa diindikatori oleh: (1) siswa belum mampu menentukan tema cerita pendek, (2) siswa belum mampu menceritakan kembali isi cerita pendek, dan (3) siswa belum mampu mengungkapkan makna dan nilai-nilai dalam cerita pendek.

Bertumpu pada daya kemampuan apresiasi cerpen siswa yang berbeda-beda, lebih ditengarai karena perbedaan kemampuan berpikir kritis dalam kegiatan pembelajaran tersebut. Pembelajaran apresiasi cerpen yang kurang melibatkan siswa secara aktif dapat mengahambat kemampuan berpikir kritis siswa yang dituangkan dalam bentuk gagasan dan pendapat (Jensen, 2011: 195).

Kemampuan berpikir kritis merupakan kegiatan berpikir untuk menganalisis ide atau gagasan ke arah yang lebih spesifik, membedakannya secara tajam, memilih mengidentifikasi, megkaji, dan mengembangkannya ke arah yang lebih sempurna. Pemikiran kritis juga merupakan pemikiran reflektif dan produktif, serta melibatkan evaluasi bukti (Wijaya, 2010: 72).

Di sisi lain, rendahnya kemampuan apresiasi siswa terhadap cerpen disebabkan oleh metode pembelajaran yang tidak disukai siswa. Guru dalam proses pembelajaran hanya bersifat sebagai subjek penyampai materi saja, bukan terfokus pada tujuan pembelajaran yang harus dicapai. Oleh sebab itu, metode-metode pembelajaran yang sering digunakan guru lebih dominan bersifat monoton, salah satunya adalah metode ceramah.

Bertolak dari uraian tersebut, diindikasikan bahwa pembelajaran cerita pendekmenggunakan metode ceramah, dan dengan penyampaian teori cerpen lebih banyak daripada kegiatan apresiasinya. Langkah-langkah pembelajaran yang seringkali diterapkan guru adalah memberikan materi cerita pendek, kemudian siswa diberi tugas di rumah untuk mengapresiasikan cerita pendek. Dari langkah pembelajaran yang diterapkan, guru terkesan mendominasi proses pembelajaran dan metodenya juga kurang inovatif. Selain itu, banyak siswa yang masih bingung mengenai cara apresiasi cerita pendek. Kegiatan pembelajaran yang demikian membuat siswa kurang tertarik untuk mengikuti pembelajaran apresiasi cerita pendek. Sisiwa merasa bosan dalam belajar karena merasa bahwa sistem pembelajaran selalu sama.

Masalah-masalah yang muncul dalam proses pembelajaran apresiasi cerita pendek membutuhkan penerapan metode pembelajaran yang baru oleh guru untuk memperbaiki kualitas pembelajaran. Berkaitan dengan hal tersebut, guru bahasa dan sastra Indonesia harus mampu membuat pembelajaran yang menarik dan sesuai dengan usia siswa. Salah satu usaha yang dilakukan adalah dengan menerapkan metode pembelajaran yang sesuai dengan materi dan usia serta menarik dan juga 
mempermudah pemahaman yang pada akhirnya bermuara padapeningkatan kualitas pembelajaran. Hal ini diperkuat dengan pendapat Rahmanto (1999: 15) menyatakan bahwa jika pembelajaran sastra dilakukan dengan cara yang tepat, maka pengajaran sastra dapat juga memberikan sumbangan yang besar untuk memecahkan masalahmasalah nyata yang cukup sulit untuk dipecahkan di dalam masyarakat.

Berdasarkan rangkaian permasalahan pembelajaran tersebut dapat diperbaiki dengan penerapan model kooperatif. Strategi pembelajaran kooperatif diambil karena pembelajaran ini memiliki berberapa kelebihan. Heri, Sugiyanto, dan Sukamto (2003: 73) menyatakan bahwa pembelajaran kooperatif mempunyai jangkauan tidak hanya membantu siswa belajar isi akademik dan keterampilan semata, namun juga melatih siswa dalam meraih tujuan-tujuan hubungan sosial dan kemanusiaan.

Mengingat banyaknya jenis metode kooperatif yang ada saat ini, maka untuk mengerucutkan model kooperatif yang ada disepakati pembelajaran apresiasi cerita pendek menggunakan metode pembelajaran Cooperative Integrated Reading andComposition (CIRC). Metode ini digunakan karena sesuai dengan jenjang pendidikan siswa dan materi cerita pendek yang diajarkan.

Hal tersebut sesuai dengan apa yang dikemukakan Slavin (2005: 11) bahwa pembelajaran dengan metode Cooperative Integrated Reading and Composition (CIRC) digunakan untuk pelajaran membaca pada kelas 2-8. Dalam pembelajaran CIRC siswa ditugaskan untuk berpasangan dalam tim mereka untuk belajar dalam serangkaian kegiatan yang bersifat kognitif, termasuk membacakan cerita satu sama lain, membuat prediksi bagaimana akhir dari sebuah cerita naratif, saling merangkum cerita satu sama lain, menulis tanggapan terhadap cerita, dan melatih pengucapan, penerimaan, dan kosakata. Dalam pembelajaran ini siswa diajak berapresiasi langsung. Hal inilah yang menjadi dasar metode pembelajaran ini tepat untuk pembelajaran apresiasi cerita pendek.

CIRC (Cooperative Integrated Reading and Composition) merupakan metode dimana siswa ditempatkan dalam tim belajar beranggotakan empat atau lima orang yang merupakan campuran menurut tingkat prestasi, jenis kelamin, dan suku. Guru menyajikan pelajaran, dan siswa bekerja dalam tim mereka. Untuk memastikan seluruh anggota tim telah menguasai pelajaran tersebut, seluruh siswa dikenai kuis tentang materi yang telah dipelajari (Slavin, 2005: 18).

Saat berkelompok siswa saling membantu menuntaskan materi yang dipelajari. Setiap anggota kelompok memiliki rasa tanggung jawab yang tinggi terhadap setiap permasalahan yang akan dibahas dalam forum diskusi. Dengan demikian anggota kelompok akan dapat memahami setiap permasalahan yang ada, sehingga saat kuis individu siswa mampu mengerjakan dengan baik. Guru memantau dan mengelilingi tiap kelompok untuk melihat adanya kemungkinan siswa yang memerlukan bantuan. Metode ini pun dibantu oleh metode pelatihan, penugasan, dan tanya jawab sesuai satuan pelajaran, sehingga ketuntasan materi akan terwujud.

\section{Metode Penelitian}

Penelitian ini dilaksanakan di SDN Mrayan Kecamatan Ngrayun Kabupaten Ponorogo selama 1 (satu) semester di semester gasal tahun pelajaran 2016/2017.Penelitian ini termasuk ke dalam jenis penelitian kuantitatif eksperimen semu. Desain penelitian menggunakan Anava 2x2.Populasi dalam penelitian ini adalah seluruh 
siswa SDN Mrayan 1 sampai dengan SDN Mrayan 6. Sampel dalam penelitian ini sebanyak 100 orang siswa kelas VI SDN Mrayan 1 hingga SDN Mrayan 6.Teknik pengumpulan data dalam penelitian ini ada 2, yaitu dengan angket dan tes berskala Liekert.

\section{Hasil dan Pembahasan}

1. Ada Pengaruh Penggunaan Model Pembelajaran CIRC Terhadap Kemampuan Apresiasi Cerpen Siswa SDN Mrayan Kabupaten Ponorogo (Hipotesis Pertama)

Dari analisis statistik yang telah dilakukan diperoleh nilai signifikansi sebesar $0,000<0,05$. Hal tersebut mengandung arti bahwa ada perbedaan kemampuan apresiasi cerpen siswa yang diajar menggunakan model pembelajaran CIRC dengan model pembelajaran non CIRC. Berdasarkan temuan ini, dapat dikemukakan bahwa kemampuan apresiasi cerpen siswa dapat dioptimalkan melalui penggunaan model pembelajaran yang sesuai. Pembelajaran apresiasi cerpen identik dengan membaca. Hal tersebut sesuai dengan fakta di lapangan bahwa seseorang yang senantiasa dilatih dengn membaca, maka kemampuan apresiasi cerpennya juga akan meningkat.

Pada model pembelajaran CIRC terdapat pengajaran membaca dan menulis. Tidak hanya itu, peserta didik bekerja dalam tim belajar kooperatif beranggotakan empat orang mereka terlibat dalam sebuah rangkain kegiatan bersama termasuk saling membacakan satu dengan yang lain membuat prediksi tentang bagaimana cerita dan berlatih pengejaan serta perbendaharaan kata. Hal ini sejalan dengan pendapat Heri, Sugiyanto, dan Sukamto (2003: 73) menyatakan bahwa pembelajaran kooperatif mempunyai jangkauan tidak hanya membantu siswa belajar isi akademik dan keterampilan semata, namun juga melatih siswa dalam meraih tujuan-tujuan hubungan sosial dan kemanusiaan. Siswa juga bekerja sama untuk memahami ide pokok dan keterampilan pemahaman yang lain, sehingga dapat dipastikan kemampuan apresiasi cerpen siswa juga akan meningkat.

\section{Ada Pengaruh Kemampuan Berpikir Kritis Terhadap Kemampuan Apresiasi Cerpen Siswa SDN Mrayan Kabupaten Ponorogo (Hipotesis Kedua)}

Berdasarkan hasil analisis data yang telah dilakukan, diperoleh nilai kemampuan apresiasi cerpen siswa yang memiliki kemampuan berpikir kritis tinggi dan siswa yang memiliki kemampuan berpikir kritis rendah adalah sebesar sig $\rho=0,000<0,05$. Hal tersebut berarti $\mathrm{HO}$ ditolak, sedangkan $\mathrm{H} 1$ diterima. Hal ini membuktikan bahwa terdapat perbedaan kemampuan apresiasi cerpen siswa yang memiliki kemampuan berpikir kritis tinggi dengan kelompok siswa yang memiliki kemampuan berpikir kritis rendah. Atau kemampuan berpikir kritis berpengaruh terhadap kemampuan apresiasi cerpen siswa.

Dari hasil temuan ini dapat disimpulkan bahwa kemampuan berpikir seseorang ikut berperan dalam memaksimalkan potensi yang ada dalam dirinya. Kemampuan berpikir kritis sebagai faktor internal yang ada dalam diri siswa sangat mempengaruhi kemampuan apresiasi cerpen. Hal tersebut dikarenakan pembelajaran apresiasi karya sastra seperti cerpen memerlukan tingkat kemampuan berpikir yang tinggi.

Di sisi lain, berpikir kritis merupakan berpikir yang rasional. Artinya kemampuan berpikir kritis lebih bersifat pemerolehan hasil pemikiran yang rasional, atau berdasrkan realita yang ada. Proses berpikir kritis memerlukan kemampuan untuk mengevaluasi 
suatu pernyataan dan mengidentifikasi suatu alasan, misalnya bukti yang melandasi evaluasi tersebut. Hal ini sesuai dengan pendapat Wijaya (2010: 72) bahwa pemikiran kritis juga merupakan pemikiran reflektif dan produktif, serta melibatkan evaluasi bukti. Maka dari itu kemampuan apresiasi cerpen sangat bergantung pada kemampuan berpikir kritis yang dimiliki siswa.

\section{Ada Interaksi Antara Penggunaan Model Pembelajaan CIRC dan Kemampuan Berpikir Kritis Terhadap Keampuan Apresiasi Cerpen Siswa SDN Mrayan Kabupaten Ponorogo (Hipotesis Ketiga)}

Berdasarkan hasil penghitungan ANAVA dua jalan diperoleh nilai sig $\mathrm{F}$ sebesar $0,000<0,05$ berarti HOAB ditolak. Adanya interaksi ini bermakna terdapat ketidak konsistensian efek atau pengaruh penggunaan model pembelajaran CIRC terhadap kemampuan apresiasi cerpen siswa ditinjau dari kemampuan berpikir kritis dan terdapat ketidak konsistensian efek atau pengaruh kemampuan berpikir kritis terhadap kemampuan apresiasi cerpen ditinjau dari penggunaan model pembelajaran CIRC.

Berpedoman pada hasil temuan ini, diketahui bahwa tidak hanya kemampuan berpikir saja yang dapat mempengaruhi kemampuan siswa, tetapi juga penggunaan model pembelajaran yang seseuai ikut menunjang kemampuan apresiasi cerpen siswa. Apresiasi cerpen memerlukan kemampuan berpikir yang tajam dalam menafsirkan hal yang tersirat maupun yang tersurat dari sebuah bacaan. Namun faktor internal saja tidaklah cukup. Hal tersebut juga harus ditunjang oleh adanya faktor eksternal, yaitu penggunaan model pembelajaran CIRC. Dengan adanya model pembelajaran CIRC, ikut mempertajam kemampuan berpikir kritis siswa dan selanjutnya akan berpengaruh pula terhadap kemampuan apresiasi cerpen siswa.

\section{Kesimpulan}

Dari penelitian yang telah dilakukan, dapat ditarik kesimpulan bahwa; (1) terdapat pengaruh penggunaan CIRC terhadap kemampuan apresiasi cerpen siswa; (2) terdapat pengaruh kemampuan berpikir kritis terhadap kemampuan apresiasi cerpen siswa; dan (3) terdapat interaksi antara penggunaan CIRC dan kemampuan berpikir kritis terhadap kemampuan apresiasi cerpen siswa.

\section{Daftar Pustaka}

Ahmadi, Abu \& Supriyono, Widodo. 2004. Psikologi Belajar. Jakarta: Rineka.

Ahuja, Pramila. 2010. Membaca Secara Efektif dan Efisien. Bandung: Kiblat.

Danarjati, D.P dkk. 2013. Pengantar Psikologi Umum. Yogyakarta: Graha Ilmu.

Danim, Sudarwan. 2011. Pengantar Kependidikan: Landasan, Teori, dan 234 Metafora Pendidikan. Bandung: Alfabeta.

Depdiknas. 2007. Metode Pembelajaran Bahasa Indonesia. Jakarta: Balai Pustaka.

Djaali, dkk. 2007. Pengukuran Dalam Bidang Pendidikan. Jakarta: Grasindo. 
Fauzi. 2004. Teori Persepsi. Jakarta: Rineka Cipta. 